\title{
Simulation of the movement of the supporting leg of an exoskeleton with two links of variable length in 3D
}

\author{
A. Blinov' ${ }^{1}$ A. Borisov' $1^{*}$, L. Konchina ${ }^{1}$, M. Kulikova ${ }^{1}$, K. Maslova ${ }^{1}$ \\ ${ }^{1}$ Branch of the National Research University "MPEI" in Smolensk, Smolensk, Russia \\ *BorisowAndrej@yandex.ru
}

\begin{abstract}
A two-link model of exoskeleton with variable-length links for supporting the lower limbs of the human musculoskeletal system is proposed in the article. The researched model differs from the existing ones by the variable-length links, and by the angle calculation method. While in the existing models, the angles are calculated from the regular direction from vertical, or from horizontal, - in the proposed research they are calculated between the links. As for practical exoskeleton implementation, the proposed method of angle calculation is appropriate to the actual working conditions of the electrical motors with the reduction gears installed in the hinges, which change the angles between the links. The construction of a variable-length exoskeleton link consists of two absolutely solid weighty sections located at both ends of the link and one weightless section between them in the center of the link. In the weightless section, there is a drive that creates a control longitudinal force, which realizes the increase or decrease in the length of the link in the required manner and provides the necessary maintenance of the length of the link when the person moves in the exoskeleton. The links are connected to each other using spherical hinges. Drives are installed in each hinge, creating control torques, which provide a relative rotational movement of the links. The jointly controlling longitudinal forces and moments realize the maintenance of the posture or the movement of the link in the required manner and, in relation to the exoskeleton, the repetition of the basic biomechanical properties of the human musculoskeletal system. The mathematical model in the form of the system of Lagrange differential equations of the second kind is obtained. The obtained mathematical model is examined for existence and uniqueness of the Cauchy solution. The kinematic trajectory of the link motion has been synthesized, which simulates the anthropomorphic movement of the supporting leg during the single-support phase of movement, and the control actions required for its implementation has been found. The significance of the results obtained in the process of modeling lies in the ability to create active exoskeletons, prostheses in medicine, anthropomorphic robots, and spacesuits that take into account the biomechanical features of the functioning of the human musculoskeletal system.
\end{abstract}

Keywords: exoskeleton, hinge, variable-length link, human musculoskeletal system, angle between links, local system of coordinates, controlling forces and torques

For citation: Blinov A., Borisov A., Konchina L., Kulikova M., Maslova K. Simulation of the movement of the supporting leg of an exoskeleton with two links of variable length in 3D. Prikladnaya informatika=Journal of Applied Informatics, 2021, vol.16, no.4, pp.122-134. D0I: 10.37791/2687-0649-2021-16-4-122-134 


\title{
Моделирование движения опорной ноги экзоскелета с двумя звеньями переменной длины в 3D-пространстве
}

\author{
А. О. Блинов ${ }^{1}$, А. В. Борисов ${ }^{*}$, Л. В. Кончина ${ }^{1}$, М. Г. Куликова ${ }^{1}$, К. С. Маслова ${ }^{1}$ \\ 1 Филиал ФГБОУ ВО «Национальный исследовательский университет "МЭИ"» \\ в г. Смоленске, Смоленск, Россия \\ *BorisowAndrej@yandex.ru
}

\begin{abstract}
Аннотация. В статье предложена модель двух звеньев экзоскелета переменной длины для поддержки нижних конечностей опорно-двигательного аппарата человека. Отличие данной работы от имеющихся заключается в использовании звеньев, изменяющих свою длину, и в способе отсчета углов, которые в других моделях отсчитываются от постоянного направления: от вертикали либо от горизонтали, а в данной работе - между звеньями. При практической реализации экзоскелета такой способ отсчета углов является адекватным реальному способу работы установленных в шарнирах электрических двигателей с редукторами, которые изменяют углы между звеньями. Конструкция звена экзоскелета переменной длины представляет собой два абсолютно твердых весомых участка, расположенных на обоих концах звена, и один невесомый участок между ними в центре звена. В невесомом участке расположен привод, создающий управляющую продольную силу, реализующую увеличение или уменьшение длины звена требуемым образом и обеспечивающую необходимое поддержание длины звена при движении человека в экзоскелете. Звенья соединяются между собой при помощи сферических шарниров. В каждом шарнире установлены приводы, создающие управляющие моменты, которые обеспечивают относительное вращательное движение звеньев. Совместно управляющие продольные силы и моменты реализуют поддержание позы или перемещение звена требуемым образом и, применительно к экзоскелету, повторение основных биомеханических свойств опорно-двигательного аппарата человека. Получена модель в виде системы дифференциальных уравнений Лагранжа второго рода. Проведено исследование полученной математической модели на существование и единственность решения задачи Коши. Синтезирована кинематическая траектория движения звена, моделирующая антропоморфное движение опорной ноги во время одноопорной фазы движения, и определены управляющие воздействия, необходимые для ее реализации. Значимость заключается в возможности создавать учитывающие биомеханические особенности опорно-двигательного аппарата активные экзоскелеты и протезы.
\end{abstract}

Ключевые слова: экзоскелет, шарнир, звено переменной длины, опорно-двигательный аппарат человека, угол между звеньями, локальная система координат, управляющие силы и моменты

Для цитирования: Блинов А. О., Борисов А. В., Кончина Л. В., Куликова М. Г., Маслова К. С. Simulation of the movement of the supporting leg of an exoskeleton with two links of variable length in 3D // Прикладная информатика. 2021. T. 16. № 4. С. 122-134. D0I: 10.37791/2687-0649-2021-16-4-122-134

\section{Introduction}

W hen creating models of humanoid mechanisms, biological prototypes from nature are used. In this article, the exoskeleton motion simulation is based on empirical information about geometry and inertial characteristics of the musculoskeletal system of a particular person. The research in the construction of anthropomorphic robots and exoskele- 